\title{
Overvektige trengte mye støtte for å endre livsstil
}

Utvalg og oversettelse ved

\author{
Liv Merete Reinar
}

Illustrasjonsfoto: Colourbox

Hvordan beskriver overvektige sin opplevelse under forsøk på vektreduksjon? Hva tror de kan hjelpe dem å gå ned i vekt?

\section{DESIGN}

Kvalitativ studie

\section{SETTING}

Victoria, Australia

\section{DELTAKERE}

Bekvemmelighets- og hensiktsmessig utvalg av 76 personer (gjennomsnittsalder 47 år, 83 prosent kvinner) som hadde kroppsmasseindeks $>30$.

\section{METODE}

Data ble innhentet ved intervjuer eller telefonintervjuer. Intervjuene ble tatt opp på bånd og transkribert. Data ble analysert tematisk og kategorisert («constant comparison»).

\section{HOVEDFUNN}

1. Motivasjon for diett. Blant annet: overordnet helse og velvære, råd fra helsepersonell, og sosial aksept. En deltaker sa: «... Jeg holder meg til dietten slik at jeg går ned i vekt og kan få på meg et skjørt som jeg ønsker å bruke». 2. Vektreduk- sjonsteknikker. Deltakerne gikk fra «fad» dietter som tenåringer til mer kommersielle dietter som «Weight Watchers» og «Jenny Craig». For mange var gruppedeltakelse en sosial aktivitet som de delte med familie og venner. Noen deltakere følte tilhørighet til gruppa, men grupper kunne også underbygge følelsen av lavt selvbilde, negative følelser og selvklandring. Når dietter ikke førte fram prøvde noen deltakere mer ekstreme metoder som svært lavt kaloritilskudd eller medikamenter. Deltakere som prøvde medikamenter var generelt fornøyd med vektreduksjon, men ikke med bivirkningene fra medikamentene. 3. Kort-og langtidseffekt av tiltakene. De fleste deltakerne gikk ned i vekt når de var på diett, følte seg «euforiske» og hadde bedre fysisk velvære. Likevel, det ikke å opprettholde vektreduksjonen over tid førte til folelse av mislykkethet, depresjon og sinne. 4. Hvorfor virker ikke dietter? Noen deltakere mente at dietter var «umulig å holde», «kjedelige» eller «for dyre». En deltaker «ville bare være normal» uten restriksjoner. Mange følte at diettene kunne gi resultater: «Alle virker ... når du holder deg til dem. Det er når du ikke holder deg til dem at de ikke virker». Noen deltakere skyldte på seg selv eller på livshendelser når de sluttet med et vektreduksjonsprogram. Noen opplevde press fra familie og venner dersom de gikk mye ned i vekt: «Jeg var bare totre kilo fra målet og alle rundt meg var paniske og sa at jeg ikke spiste nok.» 5. Fysisk aktivitet. Få deltakere brukte fysisk aktivitet for å gå ned i vekt. De fleste erfarte at trening var vanskelig på grunn av vekten, helseproblemer, kostnader, tidsmangel eller at de var flaue. En kvinne gikk morgentur klokken fem for å unngå å bli sett av noen. Deltakerne syntes det var vanskelig å trene alene og ønsket at noen andre kunne motivere dem. 6 . Hva virker? De fleste deltakerne følte at forskjellige tilnærminger til vektreduksjon ville være nyttig for forskjellige personer; de fleste sa at diett var nyttig, få nevnte fysisk aktivitet. Mange sa at det var vanskelig å gå ned i vekt alene og ønsket støtte fra andre, for eksempel fra helsepersonell i primærhelsetjenesten. Noen syntes det var vanskelig å oppsøke hjelp på grunn av stigmatisering forbundet med overvekt, og mange følte at støttegrupper med andre overvektige kunne være nyttig. Én deltaker kommenterte: «Det handler om å myndiggjøre store personer slik at de kan gjøre valg som vil kunne bedre livsstilen og livet. Det burde ikke handle om vektreduksjon ...»

\section{KONKLUSJON}

Personer som var overvektige var ofte på diett, men opplevde at slike programmer burde ha med flere perspektiver og livss- 


\section{$=-$
$\begin{gathered}\text { Evidence-Based } \\ \text { Nursing }\end{gathered}$ \\ BMJIJournals}

tilsforandringer. De trengte kontinuerlig støtte for å kunne gjøre endringer.

Sammendrag: Thomas SL, Hyde J, Karunaratne A, et al. "They all work ... when you stick to them»: a qualitative investigation of dieting, weight loss, and physical exercise in obese individuals. Nutr J 2008;7:34.

Korrespondanse til: $\operatorname{Dr} S$ L Thomas, Monash University, Prahran, Victoria, Australis; Samantha.thomas@med.monash. edu.au

Finansiering: Bellberry Limited through Monash Foundation.

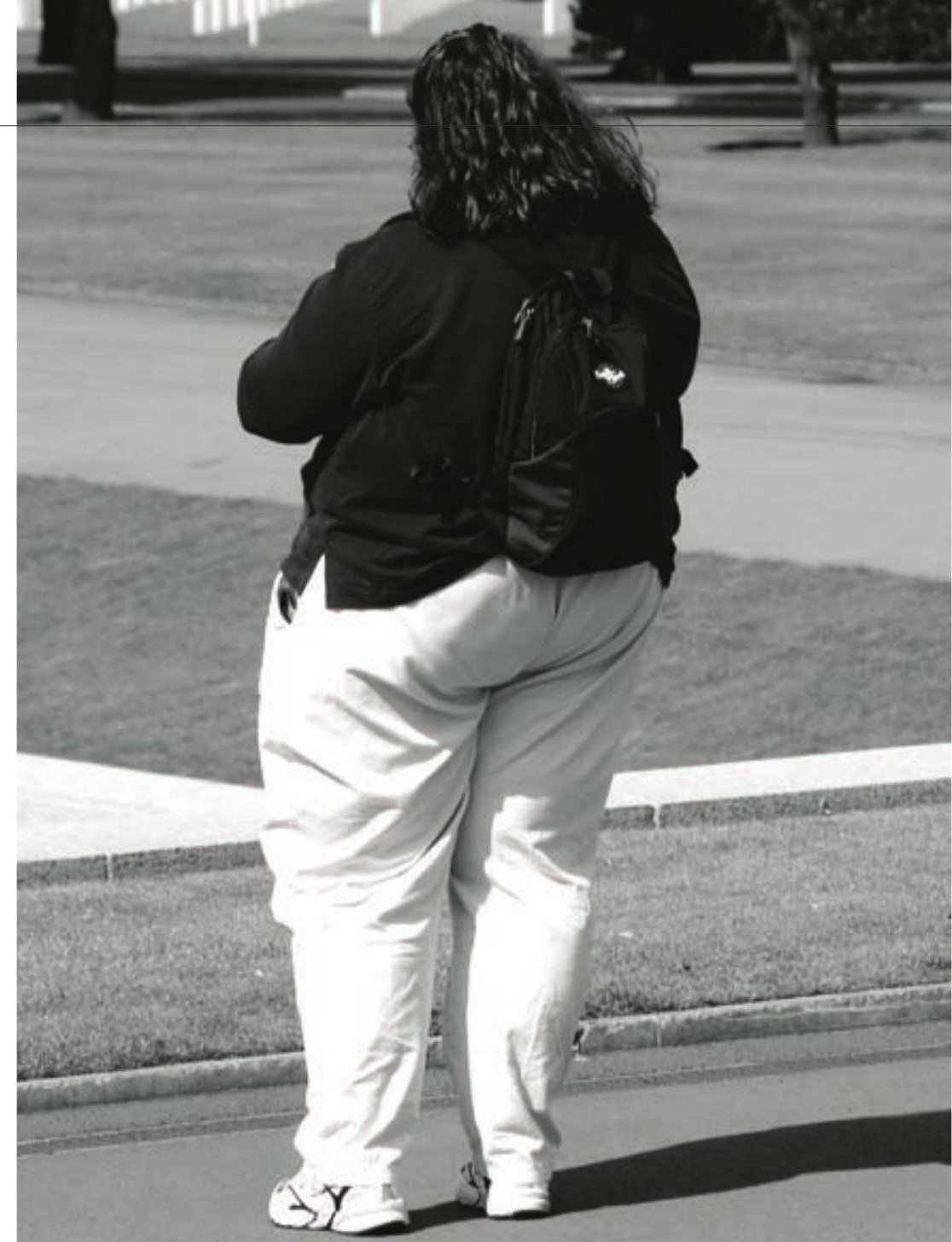

Denne studien til Thomas og medarbeidere støtter det vi lenge har visst: å gå på diett er vanskelig og fører til negative følelser. Deltakerne trengte noe som var tilgjengelig, rimelig, med langtidsperspektiv og som også inkluderte positiv støtte. Selv om deltakerne erkjente at det var behov for livsstilsendringer så var diett den mest framtredende tilnærmingen. Mange mente at helsepersonell kunne hjelpe dem. Noen hadde negative følelser for gruppeprogram (diett). Sykepleiere kan møte slike negative følelser og tilby støtte mens de oppfordrer til realistiske livsstilsendringer.

Vi må vite hva som virker og dele denne kunnskapen med personer som ønsker å gå ned i vekt. «National Weight Control Registry» har dokumentert strategier basert på medlemmer som har opprettholdt en gjennomsnittlig vektreduksjon på 30 kg > fem år. Disse strategiene var: høyt nivå av fysisk aktivitet lomtrent en time per dag); lavkalori - og lite fett i kosten; regelmessig frokost; egenovervåking av vekt; og å opprettholde konsistent spisemønster på hverdager og i helgene (1). Dette er nøkkelfunn i forhold til livsstil. Mange deltakere i studien til Thomas hadde ikke trening med i sine programmer. En systematisk Cochrane-oversikt støtter rollen fysisk aktivitet har med henblikk på å redusere diastolisk blodtrykk, triglyserider og fastende blodsukker. som er assosiert med overvekt (2). Trening og diett virker bedre enn diett alene for å oppnå vektreduksjon, men trening var assosiert med reduksjon i risikofaktorer for hjertesykdom selv om man ikke gikk ned i vekt (2).

Denne studien av Thomas gir noen direktiver sykepleiere kan bruke for å gi kunnskapsbasert støtte til personer som er overvektige. En kombinasjon av individuelle, gruppebaserte og lokalbaserte tiltak, og å unngå ordet «diett» kan hjelpe overvektige til å ta i bruk én livsstilsstrategi av gangen og bli «vinnere».

Kathy Shadle James, NP, DNSc, University of San Diego, Hahn School of Nursing and Health Science, San Diego, California, USA.

1. Wing RR, Phelan S. Am J Clin Nutr 2005;82:222S-5S

2. Shaw K, Gennat H, O'Rourke P, et al. Cochrane Database Syst Rev 2006;(4): CD003817.

(c) Evidence Based Nursing (EBN) juli 2009 vol 12 no 3 